\title{
Findings About Events or Interventions Subcategory
}

National Cancer Institute

\section{Source}

National Cancer Institute. Findings About Events or Interventions Subcategory. NCI

Thesaurus. Code C87891.

A subdivision of findings data. 